\title{
Cracking on the surface of concrete multi-storey car parks - causes and repair
}

\author{
Beata Ordon-Beska1
}

\begin{abstract}
:
This work focuses on scratches on the concrete slabs of open and closed multi-storey car parks. Cross and surface scratches as well as scratches formed above the reinforcing bars are presented. The reasons for their occurrence, how to prevent them and methods of repair are given. The work is illustrated by an example of the occurrence of cracks over the reinforcement, on which rusty blooms are visible indicating the corrosion of the reinforcement and the concrete bulges resulting from it. The surface, linear measurements of the cover thickness made with the Profometr PM-650 device are presented. These tests show that the reinforcement has been placed carelessly and the thickness of the cover is much smaller than that required for durability. The submitted applications relate to the design, construction and maintenance of the facility.
\end{abstract}

\section{KEYWORDS}

concrete surface; cracking mechanism; cover thickness; diagnostics; repair

\section{Introduction}

With the progressive increase in traffic and the popularity of vehicle ownership, the demand for parking spaces is growing. Due to the desire to reach city centers, where the development is dense and the cost of land purchase high, both closed and open multi-storey parking lots are being built more and more often. Architectural considerations also result their construction. Structural elements of these facilities are exposed to a number of external factors resulting in their degradation, such as climatic conditions and factors related to the facility's function. There are also design and construction errors [1], and improper maintenance. As a result, damage appears on the structure [2-4] some of which may, in the long run, lead to the loss of functional properties or even threaten their safety.

In order to avoid serious threats, multi-storey car parks - like other building structures should be inspected according to a strictly defined schedule, and any damage should be inventoried and assessed in terms of the cause of its creation and its impact on the operation and durability of the facility. The damage to parking facilities includes, but is not limited to, scratching of the pavement.

\section{Types of cracks on parking surfaces, their causes and prevention}

\subsection{Cross cracks}

Cross-cracks [3-6] are quite common damage. They can arise as a result of local overloading of the floor, insufficient number of dilatations in the base, or as a result of shrinkage [2]. In the

1 Czestochowa University of Technology, Faculty of Civil Engineering, ul. Akademicka 3, 42-218 Czestochowa, e-mail: b.ordon-beska@pcz.pl, orcid id: 0000-0003-2236-6065 
case of floors on the ground, cracks are caused by insufficient or uneven compaction of the soil, or insufficient understanding of the ground in re-built objects, or through leaving old infrastructure elements in place [1]. Cross-cracks also arise when the surface of the priming concrete is not smoothed before the sliding layer of PVC foil is applied or the underlay concrete is cracked. Among other reasons, there are also poorly selected concrete composition, alkaline reaction of aggregate and improper concrete care. Cracking occurs as a result of exceeding the tensile stresses due to operational loads and exceeding the permissible shrinkage and thermal stresses [2].

In order to prevent the formation of shrinkage cracks, it is necessary to carefully consider possible deformations and properly arrange expansion joints in the base layer. The area should also be properly prepared for the application of the sliding layer. In the case of floors on the ground, ground conditions should be examined in detail and measures should be taken to properly prepare the ground. The composition of the concrete should be selected to prevent excessive shrinkage stresses.

\subsection{Cracks over the reinforcement bars}

Such cracks [3] arise as a result of plastic settling of non-hardened concrete [2] and its spontaneous consolidation by reinforcement. The large diameter of the reinforcement is important here. In order to prevent the formation of such cracks, the smallest possible diameter of the reinforcement should be selected, and the concrete mix should be selected so that the cone slump is as low as possible. The zones of the reinforcement plant should be as short as possible, but should also take into account all the recommendations of PN-EN 1992-1-1.

The thickness of the cover should be selected according to the exposure classes XD3 (corrosion due to chlorides not originating from sea water) and XF4 (cyclically wet and dry structures). It should not be less than $4 \mathrm{~cm}$. When determining the nominal cover, take into account the class of manufacturing tolerance and the resulting possible reduction of the cover thickness during the execution of the structure by the deviation value $\Delta \mathrm{c}_{\mathrm{dev}}$, for which the recommended value is $1 \mathrm{~cm}$. Concrete should be at least C30/37 class. The PN-EN 206-1 standard recommends that for the XF4 class, the $\mathrm{w} / \mathrm{c}$ ratio should not exceed 0.45 , and the amount of cement should be at least $340 \mathrm{~kg} / \mathrm{m}^{3}$. In order to prevent the effects of crack development and the corrosion progression of the reinforcement, CEMII cement, which is characterized by a fairly high degree of frost resistance, should be used. It is advantageous to add synthetic fibers to the concrete mix, which helps increase the tensile strength of concrete [7].

\subsection{Surface cracks}

The surface cracks $[2,6,8]$ include contraction cracks resulting from autogenous, i.e. shrinkage resulting from chemical reactions in the binding mixture and the evaporation or drainage of water from the surface of non-hardened concrete. The water requirement in the upper layers of the floor is high due to the presence of more cement. Also, the use of mineral sprinkles increases this demand, and mechanical scuffing of the surface reduces the $\mathrm{w} / \mathrm{c}$ ratio. The image of such scratches is called "crocodile skin" due to the appearance of the resulting grid of scratches. They are also referred to as hairline scratches [9]. Scratching occurs when the upper layers of concrete contain more water after care, which will evaporate. Scratching is also observed on the contact surface of the cement paste and coarse aggregate. Plastic shrinkage also contributes to the formation of surface scratches. In this case, the cause is different changes in the volume of the concrete mix due to setting, at different depths of the element.

The formation of surface cracks can be prevented by proper care of young concrete: preventing overdrying, moistening. Autogenic and physical shrinkage can be limited by the appropriate selection of concrete components: the amount of aggregate, its quality, and the type of cement. Concrete slab cuts are also made to compensate for deformations. 


\section{Repair of floors}

Repairs of floors should be carried out in accordance with PN-EN 1504-9: 2010 [10] and PN-EN 1504-10: 2017-12 [11]. The first of the standards specifies the principles of repair and protection, and the second specifies repair and protection methods.

Repairing the floors in terms of the damage described in point 2 includes, depending on their cause, either the surface layers [12] or the base layer. In order to effectively perform the repair, it is necessary to select such a method and materials that should guarantee the elimination of the cause of the damage, or at least the slowing down of the rate of degradation in cases where the complete removal of the cause of the damage is not possible.

The work should begin with a detailed examination of the damage and identification of the causes of its occurrence. Next, the type of materials used in the slab and floor layers as well as all environmental and operational impacts should be identified. Based on this, it is possible to select the correct repair materials. It should also be ensured that the repair works are carried out in appropriate environmental conditions, temperature and relative humidity. Final acceptance should consist of checking the compliance of the works performed with the repair design.

Hairline scratches should be protected with primers. Detached and scratched layers are repaired by removing the detached parts and cleaning the surface of material residues, injecting scratches, and then making an interlocking layer and filling in the flooring material.

In the case of cross-cracks caused by shrinkage, it is necessary to make additional expansion joints, supplement or replace the filling of expansion joints, and install dowel bars [8]. Cross scratches should be injected with epoxy resins, and defects in the substrate should be filled with microcements.

In places where there are cracks above the reinforcement, the bulging concrete still bonded with the slab and the fully detached fragments should be removed. It is necessary to clean the reinforcement of rust and cover the concrete and the reinforcement with a tack coat, and then fill the cavities. In places where the concrete is not buckled and no rusty discoloration is visible, it is enough to inject the scratches with epoxy resins.

\section{An example of scratching the slab of an open multi-storey car park}

The observations presented below were made in the multi-storey car park open on one of the intermediate storeys, in the area next to one of the internal poles.

The structure of the floor slabs was made on a FILIGRAN type prefabricated slab. The thickness of the floor slabs is 20 and $25 \mathrm{~cm}$. Mushrooms with a height of $40 \mathrm{~cm}$ and an area of $2.5 \times 2.5 \mathrm{~m}$ have been designed above the internal poles. A $2-2.5 \mathrm{~mm}$ thick resin floor was made on the parking slab. The storey is exposed to daily and seasonal temperature changes as well as chlorides from de-icing agents. Therefore, it should meet the requirements of exposure classes XD3 and XF4.

On the upper surface of the parking slab, there are numerous scratches running in accordance with the reinforcement arrangement, directly above it, as for example in Figure 1. There are also traces of corrosion in the form of rusty discoloration and bulges running along the bars, indicating the detachment of the concrete from the rods.

In the area shown in Figure 1, the cover thickness was measured. The Profometr PM-650 was used for this purpose. A "Crossed" measurement was used, that is, a two-way measurement on a surface of freely defined dimensions. It consists of making any number of band measurements of a given width in two mutually perpendicular directions. A standard accuracy has been adopted that allows for testing the cover from 0 to $70 \div 100 \mathrm{~mm}$ with an accuracy not exceeding $\pm 2 \mathrm{~mm}$. The measurement results presented in Figure 2 indicate a large variability of the cover. It can be local even smaller than $12 \mathrm{~mm}$, and its maximum thickness may not exceed $40 \mathrm{~mm}$. The dominant cover thickness is from 13 to $25 \mathrm{~mm}$. It should be added that in the object to which the presented research relates, the author located a single rebar, the end of which protruded slightly above the floor surface. 


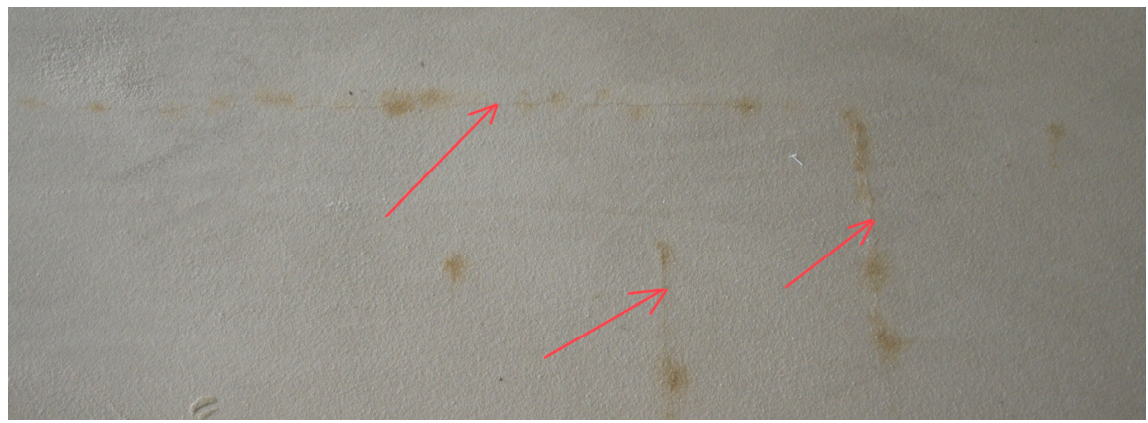

Fig. 1. Cracks over the top reinforcement bars

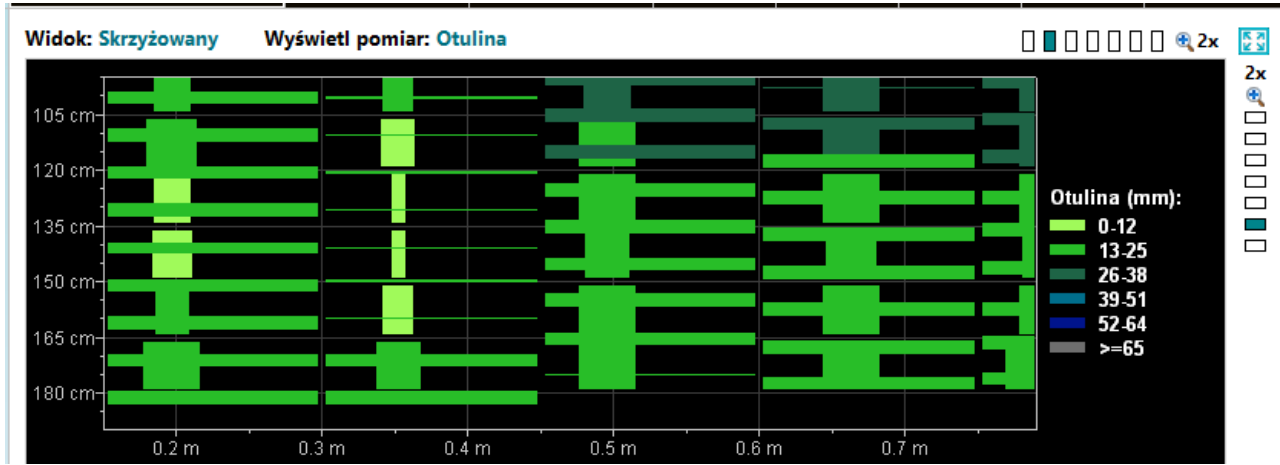

Fig. 2. Cover thickness map

Figure 3 shows the course of the buffer zone measured on a different level of the parking lot. The test was performed starting from the line connecting two adjacent columns, in the middle of the slab field length.

The drawing shows significant variability of the cover. In the presented fragment, the gap is from 32 to $40 \mathrm{~mm}$, and taking into account the measurement error, it can be at most from 33 to $41 \mathrm{~mm}$. The given range was determined after adding the measurement error of $\pm 1 \mathrm{~mm}$ to the depth of $50 \mathrm{~mm}$.

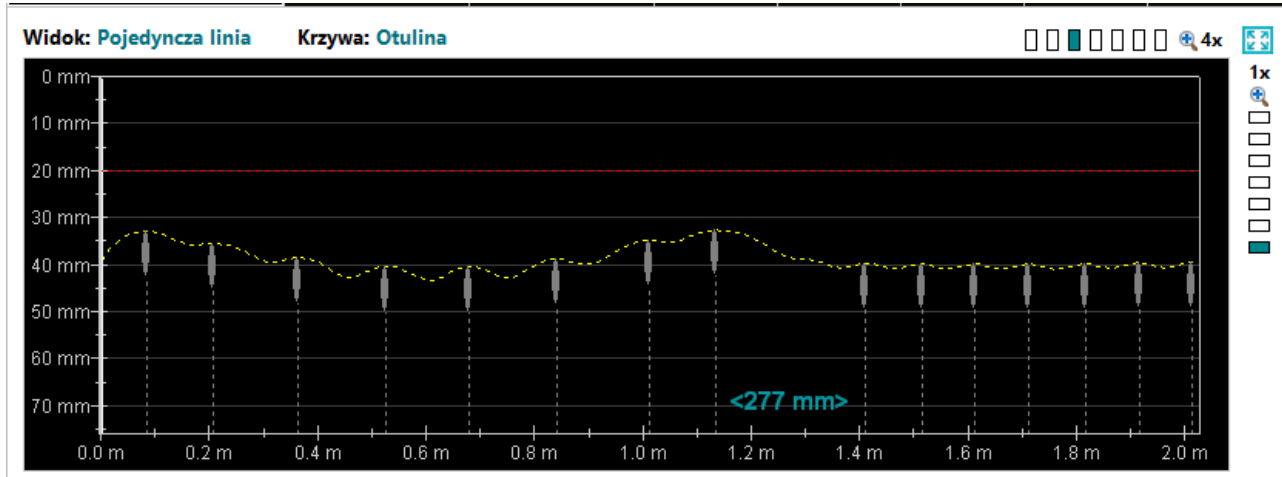

Fig. 3. An example image of the location of the reinforcement in the span area

In both presented fragments, the cover does not meet the durability requirements, because the XF4 exposure class requires that the cover of the parking slab reinforcement is at least $40 \mathrm{~mm}$ [13]. The minimum cover given in PN-EN 1992-1-1 for the XD3 class (for cyclically wet 
and dry surfaces endangered with chloride corrosion) is even more for the S4 construction class, i.e. $55 \mathrm{~mm}$.

The course of the cover thickness variability indicates a great carelessness in the arrangement of the reinforcement. There are two-way slopes on the parking deck to drain the water. However, changes in the thickness of the cover do not correspond to their shape.

Documented in Figure 1 damage is an example of the effect of making a cover of insufficient thickness. The cause of this type of cracking is plastic settling of the concrete mix and the influence of the reinforcement on its consolidation. The diameter of the reinforcement is important here, where the thicker it is, the more strongly it affects the damage presented. It should be noted that for the presented measurements, the diameter of the reinforcement $\varnothing 10$ was assumed based on the detailed design, while the measurements of the reinforcement diameter in the area covered by Figure 1 showed a diameter significantly exceeding $30 \mathrm{~mm}$. In the opinion of the author, this is not the real diameter, but the obtained results may indicate an overlap of reinforcing meshes, which, also through the local intensity of plastic settlement of concrete and its consolidation, may contribute to the described damage.

The effects of the development of the described scratches are visible in the form of rusty discoloration. The detachment of concrete above the reinforcement bars, visible in Figure 4 , is the result of corrosion development and the impact of seasonal temperature changes, i.e. freezing and thawing.

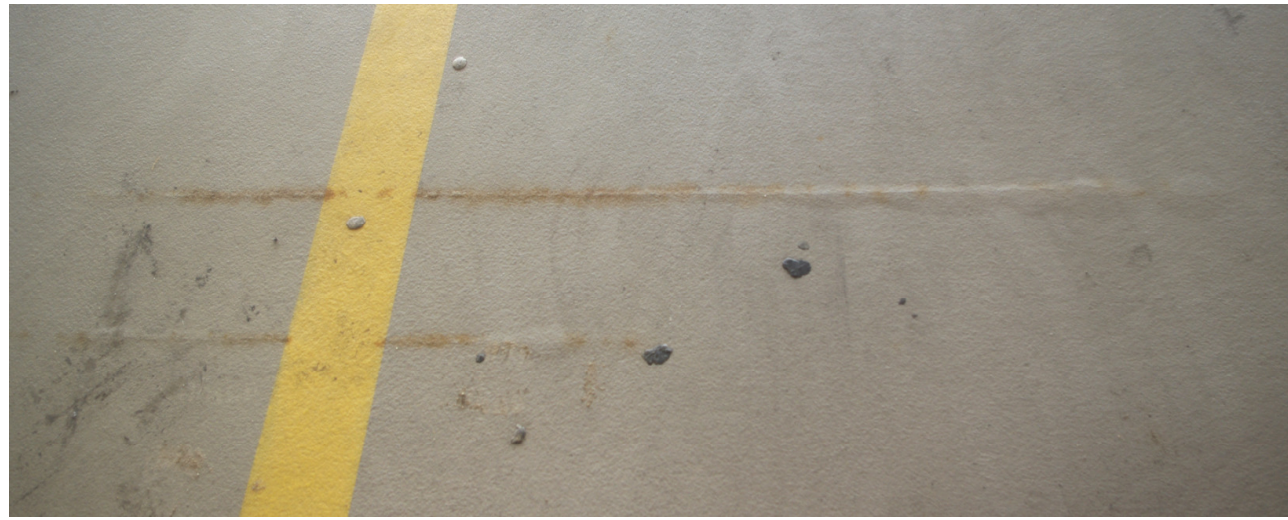

Fig. 4. Detachment of concrete along the length of the reinforcement

\section{Conclusions}

The design and construction of concrete pavements is only appears to be a relatively simple issue. Although these surfaces do not constitute a load-bearing part, improper design or careless workmanship and maintenance can significantly reduce the durability of the facility and often lead to serious problems with the repair of the facility, as well as generate a significant increase in operating costs. That is why it is so important to look for the best solution at every stage of design and execution and consider the possible consequences of the actions taken.

A serious problem is the insufficient understanding of the soil [1] and improper preparation of it as a substrate - insufficient compaction, leaving the elements of the old infrastructure.

When selecting a solution, the designer should take into account the operating conditions of the object, factors affecting the floor - for example, chemical influences, temperature changes, insolation and functionality [14]. The design must detail the location of the expansion joints in the base and the floor and their filling.

The rheological phenomena in concrete are now fairly well understood. There are a number of models describing their course, taking into account the environmental and construction conditions and the materials used. Nevertheless, it is difficult to incorporate the effects of these phenomena into the design. FEM models can be helpful here, but experience is invaluable above all. 
Construction works should be carried out under proper supervision, and the contractor should have appropriate equipment and experience.

Multi-storey car parks should be inspected for technical condition according to a strictly defined schedule, and any damage should be inventoried and assessed in terms of the cause of its creation and its impact on the operation and durability of the facility.

\section{References}

[1] Ryżyński W., Projektowanie i realizacja betonowych posadzek przemysłowych, Materiały Budowlane 2008, 9(433), 14-15, 67.

[2] Czarnecki L., Uszkodzenia i naprawy posadzek przemysłowych, Materiały Budowlane 2008, 9(433), 20-24 i 26-27.

[3] Graczyk M., Diagnostyka posadzek przemysłowych. Materiały Budowlane 2008, 9, 10-11.

[4] Dohojda M., Szulc J., Sztuka K., Diagnostyka żelbetowych elementów płytowych w obiektach parkingowych, Materiały Budowlane 2011, 11(519), 50-52 DOI:10.15199/33.2015.11.15.

[5] Z. Pająk, Ł. Drobiec, Uszkodzenia, naprawy i remonty nośnych betonowych podkładów posadzek przemysłowych, XV Ogólnopolska Konferencja Warsztat Pracy Projektanta Konstrukcji, Ustroń, 23-26 luty 2000, tom III, 231-252.

[6] Drobiec Ł., Diagnostyka i uszkodzenia betonowych posadzek przemysłowych, Izolacje 1/2017. [dostęp 24 września 2021]. https://www.izolacje.com.pl/artykul/posadzki-podlogi/177691,diagnostyka-i-uszkodzeniabetonowych-posadzek-przemyslowych.

[7] Changjun Z. i in., Impact of freeze-thaw environment on concrete materials in two-lift concrete pavement, Construction and Building Materials 2020, 262, 120070, journal homepage: www.elsevier.com/locate/ conbuildmat.

[8] Yang J. i in., Research on drying shrinkage deformation and cracking risk of pavement concrete internally cured by SAPs, Construction and Building Materials 2019, 227, 116705, Volume 48 [dostęp 24 września 2021], https://www.sciencedirect.com/science/article/abs/pii/S0950061819321233? via\%3Dihub.

[9] Chibowski T., Spękania włosowate posadzek przemysłowych, Materiały Budowlane 2008, 9(433), 41, 67.

[10] PN-EN 1504-9:2010 Wyroby i systemy do ochrony i napraw konstrukcji betonowych -- Definicje, wymagania, sterowanie jakością i ocena zgodności -- Część 9: Ogólne zasady dotyczące stosowania wyrobów i systemów.

[11] PN-EN 1504-10:2017-12 Wyroby i systemy do ochrony i napraw konstrukcji betonowych -- Definicje, wymagania, sterowanie jakością i ocena zgodności -- Część 10: Stosowanie wyrobów i systemów na placu budowy oraz sterowanie jakością prac.

[12] Ramesh G., Prakash A.R., Repair, rehabilitation and retrofitting of reinforced concrete structures by using non destructive testing methods, International Journal of Engineering Research \& Technology (IJERT), NCACE - 2020 Conference Proceedings, 9, 1, [dostęp 24 września 2021], https://www.researchgate.net/publication/ 350184935_Repair_Rehabilitation_and_Retrofitting_of_Reinforced_Concrete_Structures_By_using_Non_Destru ctive_Testing_Methods.

[13] Ryżyński W., Projektowanie, realizacja i eksploatacja betonowych nawierzchni parkingów zewnętrznych, Materiały Budowlane 2010, 9(457), 29-31.

[14] Kulas T., Przemysłowe posadzki betonowe - teoria i rzeczywistość, Materiały Budowlane 2008, 9(433), 5-8.

\section{Zarysowanie nawierzchni betonowych parkingów wielopoziomowych - przyczyny i naprawa}

\section{STRESZCZENIE:}

Praca koncentruje się na kwestii zarysowania betonowych płyt parkingów wielopoziomowych: otwartych i zamkniętych. Przedstawiono rysy skrośne, powierzchniowe i rysy powstające nad prętami zbrojeniowymi. Podane są przyczyny ich powstawania, jak zapobiegać im oraz metody naprawy. Praca zilustrowana jest przykładem występowania rys nad zbrojeniem, na których widoczne są rdzawe wykwity świadczące o korozji zbrojenia oraz wybrzuszenia betonu będące jej skutkiem. Przedstawiono powierzchniowe liniowe pomiary grubości otuliny wykonane urządzeniem profometr PM-650. Z tych badań wynika, że zbrojenie zostało ułożone niestarannie, a grubość otuliny jest zdecydowanie mniejsza niż wymagana ze względu na trwałość. Zamieszczone wnioski dotyczą projektowania, wykonawstwa i utrzymania obiektu.

\section{SŁOWA KLUCZOWE:}

nawierzchnie betonowe; mechanizm zarysowania; grubość otuliny; badania; naprawa 